\title{
Installing Piezoelectric tiles in Children Outdoor Playing areas to Create Clean \& Healthy Environment; Case Study of El-Shams Sporting Club, Cairo_Egypt
}

\author{
RANIA RUSHDY MOUSSA \\ Architectural Department \\ The British University In Egypt \\ El-Sherouk City, Cairo 11837 \\ EGYPT
}

\begin{abstract}
The pollution rate has increased during the last decades, the increasing percentage of $\mathrm{CO}_{2}$ and methane causes environmental problems such as changing in climate and rising of new diseases that jeopardize the public health. Creating a clean and healthy environment is an essential goal to protect the planet and human race. The environmental changes became a great issue all over the world especially in the developing countries such as Egypt, lately the electricity generation process and the heavy usage of fossil fuel increased the numbers of children infected by asthma and lung problems due to the air pollution. In order to have clean and healthy environment, these countries must reduce the use of non-renewable sources and replace them with clean renewable sources. Relying on non-renewable sources for electricity generation is not a suitable option anymore for the developing countries that suffers from economic problem, has no medical insurance policy and has high pollution rates such as Egypt. Children usually consumes a lot of energy during their playing period which helps them to learn and to develop their skills, it is considered one of the healthiest and most important routine for the children. This research intends to use the children movements during their playing period to generate clean energy that can be used to electrify children outdoor areas in order to create a clean and healthy environment for children in the developing countries while providing a new environmental friendly source for energy generation. The main scope Integrating piezoelectric cells in the children outdoor play sets and to use quantitative research method to calculate the average energy generated from installing the piezoelectric tiles in the children outdoor area of El-Shams sports club located in Egypt. The study will compare the energy generated from using piezoelectric cells to the club's energy consumption. The results revealed that installing piezoelectric tiles in children outdoor area generated more than $50 \%$ of energy consumed in the sports club.
\end{abstract}

Key-Words: - Children playing areas; Electricity generation; Piezoelectric tiles; Sports club.

Received: December 18, 2019. Revised: May 22, 2020. Accepted: May 31, 2020. Published: June 10, 2020

\section{Introduction}

During the eighties, researches highlighted the effects of using non-renewable energy sources on human race. Due to ignorance and the minimal actions taken toward the situation, nowadays the world is paying the price of consuming the planet resources and the heavy usage of fossil fuel. In the past few years, researchers were focusing on reducing the use of non-renewable resources and using sustainable sources in all the fields of research to protect the planet and human race. The transformation to sustainability has reached the cities design and planning, today the urban planners and designers are focusing on designing and establishing sustainable cities through implementing sustainable renewable sources of energy and recycling waste materials [1].

The environmental problems that the world is facing today can be solved through applying long term action plan for sustainable development in order to achieve sustainable cities and countries, one of the most efficient and effective way is to generate energy using renewable resources. There is a strong connection between the renewable energy and sustainable development [2].

Renewable energy plays an important role in improving the public health and environmental quality. Producing electricity using renewable energy sources instead of fossil fuels have many economic and environmental advantages. Recently, researchers were focusing on improving the efficiency of different types of renewable energy harvesting devices in order to improve the capability of renewable sources, to generate energy as much as the typical fuels regular energizes, and to reduce the carbon emissions and radioactive waste. However, the initial cost of renewable energy harvesting devices is still very high compared to fossil fuel which prevent renewable energy sources from competing with fossil fuel sources $[3 \&$ 4].

Different technologies can be used to convert energy from mechanical force or mechanical vibration to electrical energy, one of these technologies is piezoelectric cells. This research will focus on studying the effect of generating energy from piezoelectric cells in sports clubs using children movements. 


\section{Children Outdoor Play areas}

Creating healthy environment especially for the children is an important goal for researchers all over the world. Children outdoor play areas are available all over the cities around the world, with various designs and sizes. Children prosperity, security, learning and social advancement, just as their basic delight in youth, are influenced by the degree and the nature of their chances to play.

Chamber officers \& individuals, kids' administrations experts, organizers, designers, engineers, lodging chiefs, scene draftsmen \& originators, plays hardware providers, parks \& entertainment supervisors, local gatherings, wellbeing experts as well as play specialists are only a portion of the general population who have an enthusiasm for developing and providing a cheerful and charming play spaces with good vibes for kids and youngsters [5].

The children improvement of the basic social learning and aptitudes are defined and shaped through the different playing activities [5]. Through playing, youngsters figure out how to socially deal with others, to share, to arrange, and to resolve clashes, while learning self-backing abilities. Playing likewise displays the children initiative and gathering abilities. Moreover, playing is considered an instrument that kids can use to assemble their flexibility and adapting abilities, as they figure out how to explore connections and manage social challenges while overcoming their apprehensions, for instance through re-establishing dream legends [6].

\subsection{Design of children outdoor play sets}

Outdoor playing is a critical type of playing for young children. Instructors incorporate it in their daily plans, parents admonish their children to get some natural air and expressing their emotions through traditional outdoor playing [7].

Outdoor playing also provides a unique opportunity to teach children about citizenship and the important role they play in keeping the earth clean [8]. Children can understand from jumping in a pile of fallen leaves they have raked why raking is necessary. They can understand from experiencing the weather what role the rain and snow play in renewing the earth. They can watch the bird's nests and then the babies hatch in the spring. Certainly, books can presents all of these on a representational level, however, the sensory experiences and the opportunity to manipulate the components is what makes learning fun, regardless of your learning style $[7,9,10,11,12 \& 13]$

Although Outdoor playing areas have similar development patterns as interior playing areas, they are known to be more versatile and physical [14].
Comprehensive researches investigated the effects of the playgrounds design on the playing activities. Kids open air playing areas are known as vital part of youngster's development where they use their imagination and innovation while learning significant aptitudes. The children outdoor experience must include access to natural materials. Talbot and Frost defined the word 'Playscape' as an approach to consider how a specific landscape design can affect playing. Fjørtoft examined in her study how the shrubbery manages both hide-and-seek as well as imaginative play such as the playing house, while progressively solid trees would offer climbing and open spaces running 'Tag' games [14].

Designing natural landscape environments are proven to expand and boost the extent of the playing activities. Various types of loose material are significant for kids' improvement, while the transient part of exterior playing is additionally significant, with different conditions like wind, day off, sunset, warmth and cold [14].

Playing areas must be created with regards to other arrangement such as being accessible to kids and youngsters in the area. The design of children outdoor playing areas can offer kids the security that they and their families may need to participate in open air playing areas. These playing areas must be deliberately developed to offer comparative chances to the characteristics of the play-scape. There are certain basic arrangements that meets the neighborhood network such as recognizing the arrangements of holes needed, what kinds of play spaces are required, The availability of different types and sizes of play sets in order to meet all the children ages, since each specific age of children should have a special play set with special design and size as shown in table 1 [15].

Table 1. Examples of age outdoor playing sets [adapted from 15]

\begin{tabular}{|c|c|c|}
\hline AGE & $\begin{array}{l}\text { DEVELOPMENTAL } \\
\text { MILESTONES }\end{array}$ & $\begin{array}{c}\text { RECOMMENDED } \\
\text { EQUIPMENT }\end{array}$ \\
\hline $\begin{array}{l}\text { INFANTS } \\
(0-15 \\
\text { MONTHS })\end{array}$ & $\begin{array}{l}\text { - Develop on } \\
\text { individual } \\
\text { timetables } \\
\text { - Push and pull up } \\
\text { - Sit without support } \\
\text { - Crawl } \\
\text { - Cruise or walk using } \\
\text { objects or adults for } \\
\text { support } \\
\text { - Begin to stand and } \\
\text { walk alone }\end{array}$ & $\begin{array}{l}\text { - Soft surfaces } \\
\text { - Shade } \\
\text { - Tactile materials } \\
\text { - Water and sand } \\
\text { - Objects to crawl through } \\
\text { - Places to sit with adults } \\
\text { - Wind chimes and other } \\
\text { - Sensory materials } \\
\text { - Safe plants to smell and } \\
\text { - Touch } \\
\text { - Sturdys to push and pull } \\
\text { up on }\end{array}$ \\
\hline
\end{tabular}




\begin{tabular}{|c|c|c|}
\hline $\begin{array}{l}\text { TODDLER } \\
\mathrm{S} \\
(15-33 \\
\text { MONTHS })\end{array}$ & $\begin{array}{l}\text { - Become } \\
\text { increasingly mobile } \\
\text { - Push and pull toys } \\
\text { while walking } \\
\text { - Learn to climb } \\
\text { stairs } \\
\text { - Begin to use riding } \\
\text { toys (with feet on } \\
\text { ground) } \\
\text { - Run short distances } \\
\text { - Squat and balance } \\
\text { on feet while } \\
\text { playing } \\
\text { - Kick and throw } \\
\text { balls } \\
\text { - Jump in place }\end{array}$ & $\begin{array}{l}\text { - } \text { Climbing structures } \\
\text { - Slides } \\
\text { - Water and sand play } \\
\text { equipment } \\
\text { - Places to crawl through, } \\
\text { over, under } \\
\text { - Riding toys } \\
\text { - Sensory materials to } \\
\text { engage sight, sound, touch, } \\
\text { taste } \\
\text { - Structures (like } \\
\text { playhouses) for make- } \\
\text { believe } \\
\text { - Shady places to sit } \\
\text { - Loose parts for creative } \\
\text { and imaginative play } \\
\text { - Places to run, throw balls, } \\
\text { play }\end{array}$ \\
\hline $\begin{array}{l}\text { YOUNG } \\
\text { PRESCHO } \\
\text { OL (2.9-4 } \\
\text { YEARS) }\end{array}$ & $\begin{array}{l}\text { - Highest activity } \\
\text { level of any age in } \\
\text { the human life span } \\
\text { - Increasingly more } \\
\text { adventuresome } \\
\text { - Run back and forth } \\
\text { - Throw and catch } \\
\text { balls } \\
\text { - Pedal a tricycle } \\
\text { - Somersault } \\
\text { - Climb stairs } \\
\text { - Push and pull larger } \\
\text { toys like a wagon } \\
\text { - Enjoy showing off } \\
\text { climbing prowess } \\
\text { - Hop and jump } \\
\text { increasingly well }\end{array}$ & $\begin{array}{l}\text { - Structures for climbing and } \\
\text { sliding } \\
\text { - Riding toys and paths to } \\
\text { ride on } \\
\text { - Balance beams } \\
\text { - Playhouses } \\
\text { - Water and sand play } \\
\text { equipment } \\
\text { - Loose parts for pretending, } \\
\text { creating, building } \\
\text { - Talk tubes } \\
\text { - Telescopes } \\
\text { - Places to run, jump, play } \\
\text { ball } \\
\text { - Materials to enhance all } \\
\text { senses (wind chimes for } \\
\text { sound, flowers for smell) } \\
\text { - Shade to sit, eat, read, relax } \\
\text { - Places to paint, draw and } \\
\text { create }\end{array}$ \\
\hline $\begin{array}{l}\text { OLDER } \\
\text { PRESCHO } \\
\text { OL } \\
(4-5 \\
\text { YEARS })\end{array}$ & $\begin{array}{l}\text { - Physically } \\
\text { competent } \\
\text { - Climb well, enjoy } \\
\text { trying to go higher } \\
\text { and higher } \\
\text { - Enjoy challenges } \\
\text { - Roll balls } \\
\text { - Skip on alternating } \\
\text { feet } \\
\text { - Able to begin riding } \\
\text { two-wheel bike }\end{array}$ & $\begin{array}{l}\text { - } \text { Climbing and sliding } \\
\text { structures that provide } \\
\text { challenge for increasing } \\
\text { skills } \\
\text { - Bikes and paths to ride on } \\
\text { and explore } \\
\text { - Water and sand play } \\
\text { equipment } \\
\text { - Art studios } \\
\text { - Structures for imaginative } \\
\text { play } \\
\text { - Loose parts to enhance } \\
\text { play } \\
\text { - Natural features to } \\
\text { experience seasons } \\
\text { - Places to run, play ball, } \\
\text { play games }\end{array}$ \\
\hline
\end{tabular}

The Design of Natural playscapes incorporate different activities that inspire the unstructured and imaginative encounters of outdoor play. According to Pardee, Gillman, and Larson "These playing areas designs are based on the land topography which might offer for example, little mountains, slopes, and hills. They may incorporate grass, sand, mud, water, trees, bushes, and gardens". Using different surfaces and textures within the spaces, designing raised bed plantings, planting container gardens, and including sand, water, and other material in the exterior zones are considered as approaches to include the natural components within different urban environments. Sometimes the natural elements might be used for securing the playgrounds. Rather than utilizing extremely high fences to ensure playground's safety, designers might think of including lower yet more profound fencing, or planting kids- friendly materials within the playgrounds while using thick plants on the outside to give a natural hindrance. Natural playscapes offer youngsters chances to discover and build up their own play world employing natural environmental features and the free parts that are arranged and demonstrated around the play region. These areas are intended to change and develop with the different seasons and according to the youngster's interests. Usually the playing areas incorporate constructed play equipment that are consolidated within a bigger structure and are not the main focal point of the playing areas [16].

\section{Piezoelectric Cells}

Generating energy and improving the efficiency of renewable energy sources was lately the scope of various researches that were conducted to investigate the possibility of using renewable energy for energy generation through integrating renewable energy devices with urban context in order to reduce the pollution levels. [4, 17, 18, 19, 20, 21, 22 \& 23].

In the past few years, there has been expanding interest for low-power and portable-energy sources as a result of the improvement and mass utilization of convenient electronic devices. In this literature section, the components, types, materials, dimensions, energy produced, lifetime, prices and lifetime will be discussed [22].

\subsection{History of piezoelectric cells}

In 1880, Pierre and Jacques Curie found direct electric energy impact in a single gem quartz. It was noticed that, under strain, quartz generated electrical charge, this charge was known as piezoelectric. The word "piezo" means "weight" in Greek; consequently, the main meaning of the word piezoelectricity suggested "weight power" it refers to materials that have different geometric strain which generate electric field [25].

Up until the beginning of the century, piezoelectricity did not leave the labs and research centers. It was not available to the market, until a French physicist called Paul Langevin established a submarine detector that was dependent on the impact of piezoelectric in 1971. This innovation was the beginning of using the piezoelectric technology. The accomplishment of Langevin's innovation opened chances for piezoelectric materials to be used and merged in large group of different applications [26]. The first introduction of piezoelectricity to the global market was in 1945 , the discovery was based on mixed 
oxide compound (Barium titanate). It was a ferroelectric which could be effectively created and formed at a low cost and could make piezoelectric with higher constant than normal materials by an electrical poling process.

This material was a stable material and considered to be one of the essential crystal lattice structures; also lead zirconate titanate was discovered in the beginning of 1950 , which played an important role in manufacturing piezoelectric material [27].

\subsection{Types of piezoelectric cells}

There are several shapes and sizes for piezoelectric cells such as discs, rings, plates and cylinders. Each one of these shapes have different dimensions. The thickness of the piezoelectric disc ranges from $0.20 \mathrm{~mm}$ to $10.16 \mathrm{~mm}$ as shown in figure 1. The dimensions of piezoelectric ring cell can be summarized as the following; outer dimensions of the rings are range from $6.35 \mathrm{~mm}$ to $50.8 \mathrm{~mm}$ and the inner dimensions can range from $1.778 \mathrm{~mm}$ to $19 \mathrm{~mm}$ depending on the OD and thickness, while the rings thickness range from $0.2 \mathrm{~mm}$ to $10.16 \mathrm{~mm}$ depending on the material and the manufacturing company as shown in figure 1.

Another shape of the piezoelectric cells are the plates, the length and the width of the piezoelectric plates range from $2 \mathrm{~mm}$ to $48.2 \mathrm{~mm}$, while its thickness range from $0.20 \mathrm{~mm}$ to $10.6 \mathrm{~mm}$ depending on length, width and thickness of the material as shown in figure 1 .

Finally the outer dimensions of piezoelectric cylinder shape cell range from $8.9 \mathrm{~mm}$ to $22.9 \mathrm{~mm}$ and the length ranges from $3.81 \mathrm{~mm}$ to $11.5 \mathrm{~mm}$ while the minimum thickness of the wall of the cylinder is $1 \mathrm{~mm}$ as shown in figure 1 [28].
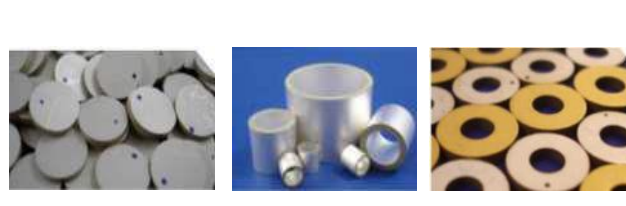

Fig.1. Piezoelectric cell shapes [28]

\subsection{Manufacturing companies of piezoelectric cells}

There are several companies manufacturing piezoelectric cells all over the world, each has different properties and price as presented in table 1 .

The piezoelectric cells have different characteristics such as: the shape, the size and the output voltage for instance, the initial cost of piezoelectric ceramic rings set that consists of two pieces range from $9.00 \$$ to $38.5 \$$, while the initial cost of the piezoelectric ceramic disc is approximately $17.78 \$$ per set which consists of two pieces, each with dimension $20 \mathrm{~mm} \times 3 \mathrm{~mm}$ [28].

The properties of piezoelectric plate cells are similar to piezoelectric ceramic generator, the average output power of this cell is $0.5 \mathrm{~mW}$ at $100 \mathrm{KHz}$ and its insulation resistance is about $100 \mathrm{M} \Omega$, with dimensions of $40 \times 10.9 \times 1.7 \mathrm{~mm}$, while its initial cost is $19.00 \$[22]$.

Piezoelectric ceramic bimorph generator is another type that used for higher output voltage, this type can be used in applications where bending force is present. Piezoelectric ceramic can produce $40 \mathrm{~V}$ under $1 \mathrm{~mm}$ deflection. The cost of one piece set of this type is 25.48\$, while the cost of piezoelectric ceramic cylinders ranges from $14.00 \$$ to $53.50 \$$ depend on the size, material and output voltage as shown in table 2 [22 $\& 28]$

Table 2. The technical specifications, price and lifespan of Piezoelectric types [22]

\begin{tabular}{|c|c|c|c|}
\hline $\begin{array}{l}\text { Company } \\
\text { Name- } \\
\text { Product }\end{array}$ & $\begin{array}{l}\text { Product } \\
\text { Dimension }\end{array}$ & $\begin{array}{l}\text { Energy } \\
\text { Generated }\end{array}$ & $\begin{array}{l}\text { Life } \\
\text { span } \\
\text { by } \\
\text { years }\end{array}$ \\
\hline $\begin{array}{l}\text { Waynergy } \\
\text { Floor }\end{array}$ & $40 \times 40 \mathrm{~cm}$ & $10 \mathrm{~W}$ per step & 20 \\
\hline $\begin{array}{l}\text { Sustainable } \\
\text { Energy floor } \\
\text { (SEF) }\end{array}$ & $\begin{array}{l}75 \times 75 \\
\mathrm{~cm} \mathrm{OR} \\
50 \times 50 \mathrm{~cm}\end{array}$ & Up to 30 watt & 15 \\
\hline Pavegen tiles & $\begin{array}{l}\text { V3 Tile } \\
50 \quad \mathrm{~cm} \text { each } \\
\text { edge }\end{array}$ & $\begin{array}{l}\text { 5Watts / } \\
\text { footsteps }\end{array}$ & 20 \\
\hline $\begin{array}{l}\text { Sound } \\
\text { Power }\end{array}$ & $\begin{array}{l}50 \times 50 \\
\mathrm{~cm} \text { tile }\end{array}$ & $\begin{array}{l}0.1 \text { watt per } 2 \\
\text { steps }\end{array}$ & 20 \\
\hline $\begin{array}{l}\text { PZT } \\
\text { ceramic } \\
\text { (Lead } \\
\text { zirconate } \\
\text { titanate) }\end{array}$ & $\begin{array}{l}\text { Manufacturing } \\
\text { in a } \\
\text { small size }\end{array}$ & $8.4 \mathrm{~mW}$ & 20 \\
\hline $\begin{array}{l}\text { Parquet } \\
\text { PVDF } \\
\text { layers }\end{array}$ & Layers & $\begin{array}{l}2.1 \mathrm{mWs} \text { per } \\
\text { pulse with } \\
\text { loads of } \\
\text { about } 70 \mathrm{~kg}\end{array}$ & 20 \\
\hline $\begin{array}{l}\text { Drum } \\
\text { Harvester s - } \\
\text { Piezo buzzer } \\
\text { Piezoelect ric } \\
\text { Ceramics } \\
\end{array}$ & Vary & $\begin{array}{l}\text { Around } 2.463 \\
\mathrm{~mW}\end{array}$ & 20 \\
\hline $\begin{array}{l}\text { hybrid energy } \\
\text { floor - which } \\
\text { integrate the } \\
\text { human power } \\
\text { with the }\end{array}$ & $1 \times 2$-meter tile & $\begin{array}{l}\text { Can generate } \\
\text { up to } 250 \\
\text { kWh } \\
\text { per year, per } \\
\text { tile }\end{array}$ & 20 \\
\hline solar energy & $\begin{array}{l}75 \times 75 \\
\mathrm{~cm} \text { tile }\end{array}$ & $\begin{array}{l}\text { up to } 250 \\
\mathrm{kWh} \text { per } \\
\text { year, per tile }\end{array}$ & \\
\hline
\end{tabular}

\section{Study Methods}

This research is conducted based on the quantitative analysis method, it intends to help in solving the energy problem in Egypt using renewable energy source to create a healthy and a clean environment. The research focuses on generating energy from piezoelectric cells installed in children outdoor play areas in order to benefit from the children movements during the playing time.

The methodology used in this research is carried out 
through calculating the amount of $\mathrm{CO}_{2}$ emissions reduction that is reduced from generating electricity using renewable energy sources and compare it with the amount of carbon emissions produced from generating the same amount of electricity using nonrenewable energy sources.

\subsection{Study Area}

El-Shams sports club was chosen to be the study area for this research, this club located in Heliopolis district, Cairo. Egypt as shown in figure 2. It was constructed in 1963, this sports club is considered one of the largest sports clubs in Egypt with total area of 480 acres. El-Shams sports club has five outdoor children playing areas, one of these areas have been selected to be the research's study area. The selected children playing areas will be used to measure the efficiency of generating energy using children movements through installing piezoelectric cells in the outdoor children playing areas.

Table 3. The visitor's density at El-Shams sport club

\begin{tabular}{lcccc}
\hline Days & $\begin{array}{c}\text { Average No. of visitors } \\
\text { during } \\
\text { Morning period }\end{array}$ & $\begin{array}{c}\text { Average No. of visitors } \\
\text { during Night } \\
\text { Period }\end{array}$ \\
\cline { 2 - 5 } & Adults & Children & Adults & Children \\
\hline Saturday & 150 & 90 & 250 & 150 \\
Sunday & 130 & 80 & 230 & 120 \\
Monday & 100 & 65 & 240 & 110 \\
Tuesday & 120 & 70 & 130 & 110 \\
Wednesday & 160 & 90 & 200 & 140 \\
Thursday & 200 & 150 & 350 & 250 \\
Friday & 270 & 220 & 370 & 200 \\
\hline
\end{tabular}

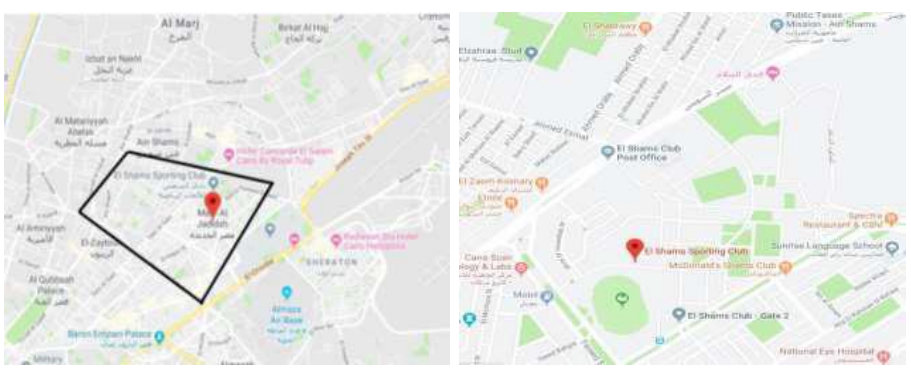

Fig.2. Location of El-Shams sport club

The selected children outdoor playing areas is located almost at the middle of the club, in front of the main swimming pool, and it includes high percentage of children and pedestrians. The total area of the selected children outdoor playing areas is $594 \mathrm{~m}^{2}$. A pedestrian path divided the selected children outdoor playing areas into two parts as shown in figure 3 .
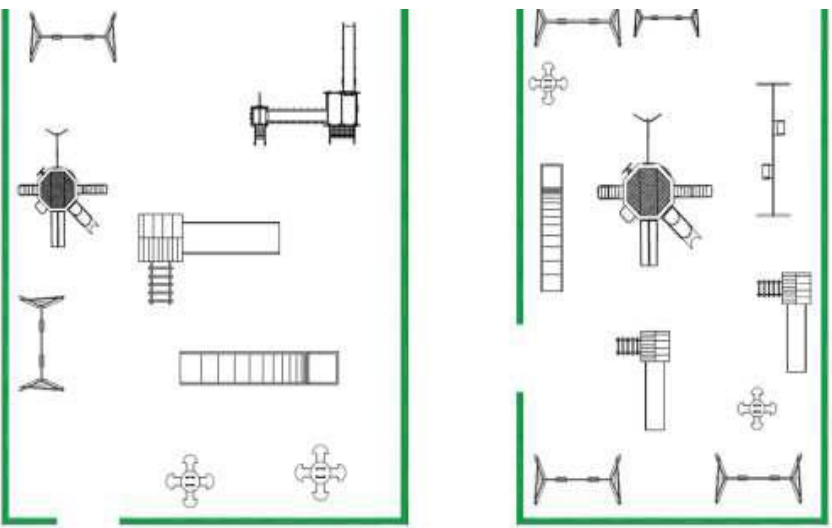

Fig.3. Children outdoor playing area at El-Shams sport club

\subsection{Data Collection}

According to the information collected from the ElShams sports club administration office, the annual electricity consumption of the sport club is around $39000000 \mathrm{kWh}$, and the average monthly electricity consumption is around $650000 \mathrm{kWh} /$ month. The electricity consumption of the club usually decrease during the winter period and increase during the summer period.

\subsection{Visitors Density:}

It was noticed that the number of visitors increased during the night period starting from $6 \mathrm{pm}$ till $12 \mathrm{am}$ and also during the weekends and vacations as shown in table 3 . The average number of visitors during the week are divided into two periods, the morning period from 6 am till $6 \mathrm{pm}$ and the night period from $6 \mathrm{pm}$ till $12 \mathrm{am}$. The number of children inside the study area vary depending on the time and days. The number of children increased in the morning periods during the weekends. However, the night period increases during the working days and school days as shown in table 3.

\subsection{Types of Piezoelectric cells}

There are many types of piezoelectric cells which can be used in children outdoor playing areas. This research concentrated on measuring the efficiency of the most suitable three types of piezoelectric tiles that can be used in the study area. Each tile was manufactured by different companies around the world and each one of these tiles has different dimensions, life span, different amount of energy generation and price as shown in table 4 . Table 4 presents the properties of three different piezoelectric tiles that can be used in children outdoor playing area of El-Shams sport club.

Table 4. The properties of piezoelectric cells

\begin{tabular}{cccc}
\hline Company & $\begin{array}{c}\text { Sustainable } \\
\text { Energy Floor }\end{array}$ & $\begin{array}{c}\text { Sound } \\
\text { Power }\end{array}$ & Pavegen \\
\hline Dimensions & $50 * 50 \mathrm{~cm}$ Tiles & $\begin{array}{c}50 \times 50 \mathrm{~cm} \\
\text { Tiles }\end{array}$ & $\begin{array}{c}50 \mathrm{~cm} \mathrm{V3} \mathrm{Tile} \\
\text { each edge } \\
\text { Estimated }\end{array}$ \\
$\begin{array}{l}\text { Life Span } \\
\text { 15 years }\end{array}$ & 20 years & 20 years
\end{tabular}




$\begin{array}{lccc}\begin{array}{l}\text { Power } \\ \text { gent/watt }\end{array} & \begin{array}{c}7 \mathrm{~W} \text { (Continued } \\ \text { power from } \\ \text { footstep) }\end{array} & \begin{array}{c}0.1 \mathrm{~W} \text { per } 2 \\ \text { steps }\end{array} & \begin{array}{c}5 \mathrm{~W} \text { (Continued } \\ \text { power from } \\ \text { footstep) }\end{array} \\ \text { Price /EGP } & 3200 & 2350 & 3500\end{array}$

The presented research compared the properties of the presented three piezoelectric tiles. "Sustainable energy floor" tiles has been selected to be used at the children outdoor play area for generating energy. After studying the selected study area, the research calculated the number of tiles needed to cover the children outdoor playing area located inside El-Shams sport club, the specific number of tiles of "Sustainable energy floor" were set according to the playing area design as shown in table 5. Table 5 presents the total costs and energy generated from installing "Sustainable energy floor" tiles in the study area of this research. According to the data presented in table 5, installing 260 "Sustainable energy floor" tiles in children outdoor playing of El-Shams sport club, will generate 1820 $\mathrm{kWh}$ and it will increase the project initial cost by 832,000 L.E.

Table 5. The number of tiles needed to generate energy using "Sustainable Energy Floor" tiles

\begin{tabular}{lcc}
\hline Number of tiles & Initial Cost L.E & $\begin{array}{c}\text { Daily Generation } \\
\text { Capacity }-\mathbf{k W h}\end{array}$ \\
\hline $\mathbf{1}$ & 3200 & 7 \\
$\mathbf{2}$ & 6400 & 14 \\
$\mathbf{3}$ & 9600 & 21 \\
$\mathbf{4}$ & 12800 & 28 \\
$\mathbf{5}$ & 16000 & 35 \\
$\mathbf{6}$ & 19200 & 42 \\
$\mathbf{7}$ & 22400 & 49 \\
$\mathbf{8}$ & 25600 & 56 \\
$\mathbf{9}$ & 28800 & 63 \\
$\mathbf{1 0}$ & 32000 & 70 \\
$\mathbf{3 0}$ & 96000 & 210 \\
$\mathbf{5 0}$ & 160000 & 350 \\
$\mathbf{1 0 0}$ & 320000 & 700 \\
$\mathbf{2 0 0}$ & 640000 & 1400 \\
$\mathbf{2 6 0}$ & 832000 & 1820 \\
\hline
\end{tabular}

\section{Results}

The main source of electricity generation in ElShams sport club is from non-renewable sources, in which it increases of the percentage of $\mathrm{CO}_{2}$ emissions and air pollution. Installing piezoelectric tiles in children outdoor playing areas can provide a clean, safe and healthy environment for Egyptian children.

Table 6: Analysis of Piezoelectric tiles at El-Shams sport club

\begin{tabular}{ll}
\hline $\mathbf{k W h}$ Needed Daily power & 2160 \\
\hline $\mathbf{k W}$ Price by Government & 1.25 \\
\hline Average Steps per day per tile & 77500 \\
\hline $\begin{array}{l}\text { Total average amount of } \mathbf{k W} \text { consumed per year } \\
\text { in EGP }\end{array}$ & $972000 \mathrm{~L} . \mathrm{E}$ \\
\hline $\begin{array}{l}\text { Total average amount of kW produced per year } \\
\text { in EGP }\end{array}$ & $751320 \mathrm{L.E}$ \\
\hline \begin{tabular}{l} 
Feasibility Price \\
\multicolumn{2}{c}{ Total Saved amount } \\
Saving percentage
\end{tabular} \\
\hline
\end{tabular}

The research analyzed and summarized the electricity consumption data collected from El-Shams sports club as well as it calculated the visitor's density in children outdoor playing area.

The aim of this research is using renewable energy sources for producing energy instead of relying on nonrenewable energy sources for electricity generation in order to reduce the $\mathrm{CO}_{2}$ emissions and create a clean and healthy environment for the children. This was done by selecting one of children outdoor play areas at El-Shams sport club and installing piezoelectric tiles to study the efficiency of this renewable energy source. The results revealed that using 260 "Sustainable energy floor" tiles can produce $1820 \mathrm{~kW}$ per day, since the average amount of energy consumed by el shams sport club was $2160 \mathrm{~kW} /$ day that means that the use of piezoelectric tiles will help in producing $83 \%$ of the total electricity needed every day. The distribution of piezoelectric tiles in El-Shams sport club are presented in figure 4.

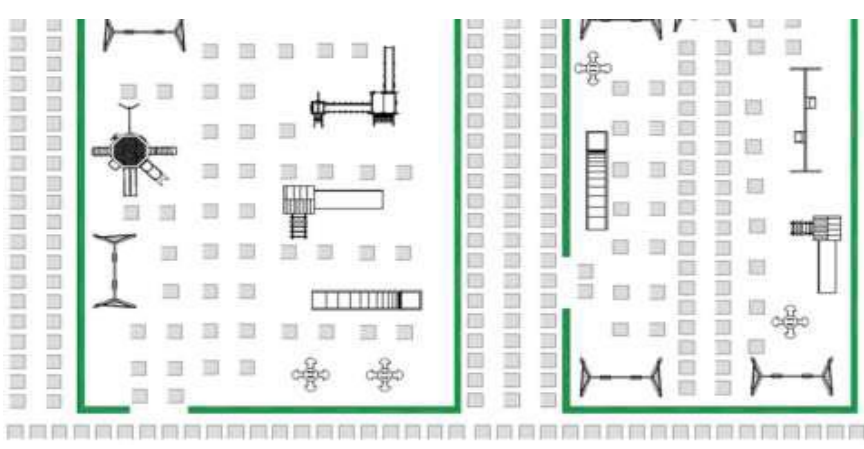

Fig. 4. Children outdoor play area at El-Shams club

The research proved that installing "Sustainable energy floor" tiles in El-Shams children outdoor playing area can produce enough energy to electrify the outdoor playing area and its surroundings through the children movements during their playing period inside the playing area. The total price of electricity generated annually from installing 260 piezoelectric tiles in children outdoor playing area is 751320 LE. Therefore, using piezoelectric tiles at children outdoor play areas have a huge economical advantage to the club, the piezoelectric tiles will save almost $77.3 \%$ of El-Shams sport club electricity bills as it is shown in table 6 . The club can use the money saved from the electricity bills for other important activities which will improve the quality of life of the people using the club and it can provide more activities and fun for the children inside the club. Using piezoelectric tiles also has social and environmental advantage since this club will participate in creating clean and healthy environment for Egyptian children through reducing the amount of $\mathrm{CO}_{2}$ emissions produced from electricity generation. 


\section{Conclusion}

Energy represents an essential part of economic development. Today, the activity of energy sector mostly depends on fossil fuel such as coal, oil and natural gas. Recently, many researches proved that fossil fuel will disappear in the next few centuries. Renewable energy is strongly recommended because of its expected need in the upcoming future taking into consideration the growth of the population and the increasing energy demands. Furthermore, the human activities are overloading the environment with carbon dioxide and global warming emissions which results in temperature increasing and their harmful effects on the health and the human body. Generating electricity by coalfired power plants and natural gas-fired power plants has significant effects on the health. Increasing the supply of renewable energy will allow the world to reduce the growth of environmental problems such as global warming and climatic change.

Energy problems are increasing every day all over the world due to relying on non-renewable energy sources for energy production which lead to the increase of the pollution level and the percentage of $\mathrm{CO}_{2}$ emissions. Depending on renewable energy sources for energy production became essentially, in order to have clean and healthy environment for the Egyptian children. This could be achieved by using piezoelectric tiles in children outdoor playing areas. Children consume high amount of power during their playing period and their movements can be used to generate high amount of energy using piezoelectric tiles. When correct number of piezoelectric tiles are used in suitable places, this will provide clean energy that can be used for different purposes. Using piezoelectric tiles at children outdoor playing area will always be beneficial in creating clean and efficient energy which in return will provide a healthy environment for the children.

\section{References:}

[1] Moussa, R.R. (2019). The Reasons For Not Implementing Green Pyramid Rating System In Egyptian Buildings. Ain Shams Engineering Journal, 10(4); 917-927.

[2] Dincer, I. (2000). Renewable energy and sustainable development: a crucial review. Renewable and Sustainable Energy Reviews, 4(2); 157-175. Retrieved from: https://doi.org/10.1016/S1364-0321(99)000118

[3] Moussa, R.R., and Mahmoud, A.H., (2017). Energy-scape Elements: An Approach on Integrating Landscape Elements with Renewable Energy Devices. Journal of Cleaner Production, 153; 114-130. Retrieved from: https://www.sciencedirect.com/science/article/pii/ S0959652617305127.

[4] Moussa, R.R., Mahmoud, A.H., and Hatem, T.M. (2020). A digital tool for integrating renewable energy devices within landscape elements: Energy-scape online application. Journal of Cleaner Production, 254; 1-13.

[5] Shackell, A., Butler, N., Doyle, P., and Ball, D. (2016). Design for Play: A guide to creating successful play spaces. Play England is a part of the National Children's Bureau and is supported by the Big Lottery Fund. Retrieved from:

https://www.playengland.org.uk/media/70684/ design-for-play.pdf

[6] Fjortoft, I. (2001). The Natural Environment as a playground for children: The impact of outdoor play activities in Pre-Primary school children. Early childhood education journal, 29(2), 111117.

[7] Theemes, T. (1999). Let's go outside: Designing the early childhood playground. Ypsilanti, MI: High Scope Press.

[8] Rivkin, M.S. (1995). The great outdoors: Restoring children's right to play outside. Washington, DC: National Association for the Education of Young Children.

[9] Piaget, J. (1926). The language and thought of the child. Orlando, FL: Harcourt Brace.

[10] Brett, A., Moore, R.C., \& Provenzo, E.F. (1993). The complete playground book. Syracuse, NY: Syracuse University Press. 
[11] Wells, N. M. (2000). At home with nature: Effects of "greenness" on children's cognitive functioning. Environment and Behavior, 32(6), 775-795

[12] Frost, J. L., Wortham, S. C., \& Reifel, S. (2001). Play and child development. Englewood Clifk, NJ: Merrill Prentice Hall.

[13] Hendricks, B.E. (2001). Designing for play. Burlington, VT: Ashgate Publishing Company.

[14] Back, J., Heeffer, C., Paget, S., Rau, A., Pysander, E.L.S. and Waern, A. (2016). Designing for Children's Outdoor Play. DIS '16: Proceedings of the 2016 ACM Conference on Designing Interactive Systems. Retrieved from:

http://dx.doi.org/10.1145/2901790.2901875

[15] CPSC. (2015). Public Playground Safety Handbook. U.S. CONSUMER PRODUCT SAFETY COMMISSION. Retrieved from: file:///C:/Users/Rania/Desktop/wseas/325.p df [last accessed 15-2-2020].

[16] Pardee, M., Gillman, A. and Larson, C. (2005). Community Investment Collaborative for Kids. Local Initiatives Support Corporation/Community Investment Collaborative for Kids. Retrieved from: https://www.lisc.org/media/filer_public/c6/ c8/c6c8b045-d3c9-46ad-ab6d65d6b807a666/2005_cick_guide_vol4_play grounds.pdf [last accessed 15-5-2020].

[17] Mao, G., Wang, S., Teng, Q., Zuo, J., Tan, X., Wang, H., Liu, Z., 2017. The sustainable future of hydropower: A critical analysis of cooling units via the Theory of Inventive Problem Solving and Life Cycle Assessment methods. Journal of Cleaner Production 142: 2446-2453.

[18] Moussa, R.R. (2018). The role of energyscape elements in creating sustainable economic project in Egyptian parks. Ain Shams Engineering Journal, 9(4); 30453053. Retrieved from: https://doi.org/10.1016/j.asej.2018.09.001

[19] Picch, P., Lierop, M.V., Geneletti, D., Stremke,S., 2019. Advancing the relationship between renewable energy and ecosystem services for landscape planning and design: A literature review. Ecosystem Services 35: 241-259.
[20] Loganathan, B., Chowdhury, H., Mustary, I., Rana, M.M., Alam, F., 2019. Design oa a micro wind turbine and its economic feasibility study for residential power generation in buitup areas. 2nd International conference on Energy and Power, ICEP2018, Sydney, Australia.

[21] Chen, J., Qiu, Q., Han, Y., Lau, D., 2019. Piezoelectric materials for sustainable building structures: Fundamentals and applications. Renewable and Sustainable Energy Reviews $101 ; 14-25$.

[22] Moussa, R.R. (2019). The Effect of PiezoBumps on Energy Generation and Reduction of the Global Carbon Emissions. WSEAS Transactions on Environment and Development, 15(46); 430-437. Retrieved from:

http://www.wseas.org/multimedia/journals/envi ronment/2019/a905115-474.pdf

[23] Solban, M.M. and Moussa, R.R. (2019). Piezoelectric Tiles Is a Sustainable Approach for Designing Interior Spaces and Creating Self-Sustain Projects. (November, 28 -30). (BSCairo2019) Simulation for a Sustainable Built Environment, Cairo Egypt. IOP Conf. Series: Earth and Environmental Science 397012020. Retrieved from: doi:10.1088/17551315/397/1/012020.

[24] Guirguis, M.N. and Moussa, R.R. (2019). Investigation on utilizing garbage as a resource for a sustainable neighbourhood; Case study of a neighbourhood in New Cairo, (November, 28 -30). (BSCairo2019) Simulation for a Sustainable Built Environment, Cairo_ Egypt. IOP Conf. Series: Earth and Environmental Science 397- 012018. Retrieved 15, December 2019, from: doi:10.1088/1755$1315 / 397 / 1 / 012018$

[25] Uchino, K. (2017). Chapter 1- The Development of Piezoelectric Materials and the New Perspective. Advanced Piezoelectric Materials (Second Edition). Science and Technology, Woodhead Publishing in Materials, 1-92. Retrieved from: https://doi.org/10.1016/B978-0-08-1021354.00001-1.

[26] Kour, R. and Charif, A. (2016). Piezoelectric Roads: Energy Harvesting Method Using Piezoelectric Technology. Innovative Energy \& Research, 5: 132, 1-6. Retrieved from: 10.4172/2576-1463.1000132. 
[27] Huo, B. (2012). The impact of supply chain integration on company performance: an organizational capability perspective. Supply Chain Management: An International Journal 17(6); 596-610. Retrieved from: 10.1108/13598541211269210.

[28] Shi, J. (2017). Ferro-electrets material in human body energy harvesting. Thesis for the degree of Doctor of Philosophy, UNIVERSITY OF SOUTHAMPTON. Retrieved from: https://pdfs.semanticscholar.org/b6d8/332f5 c133463cb85f12fbf5ec46a65576ff2.pdf 